\title{
Rapid and scalable access into strained scaffolds through continuous
}

\section{flow photochemistry}

Daniel Blanco-Ania, ${ }^{\dagger}$ Sagar Ashok Gawade, ${ }^{\dagger}$ Luc J. L. Zwinkels, ${ }^{\dagger}$ Luuk Maartense, ${ }^{\dagger}$ Marjon G. Bolster, ${ }^{\ddagger}$ Jorg C. J. Benningshof, ${ }^{\ddagger}$ and Floris P. J. T. Rutjes ${ }^{\dagger *}$

${ }^{\dagger}$ Radboud University, Institute for Molecules and Materials, Heyendaalseweg 135, 6525 AJ Nijmegen, The Netherlands

‡ Mercachem B.V., Kerkenbos 1013, 6546 BB Nijmegen, The Netherlands 


\section{3-(allylamino)cyclohex-2-en-1-one (5a)}

A solution of cyclohexa-1,3-dione $(4,10.0 \mathrm{~g}, 89.2 \mathrm{mmol})$ and allylamine $(7.64 \mathrm{~g}, 134 \mathrm{mmol})$ in toluene $(180 \mathrm{~mL})$ was refluxed using a Dean-Stark apparatus. The reaction was monitored by TLC, and upon completion $(5 \mathrm{~h})$ the mixture was evaporated under reduced pressure to give enaminone $\mathbf{5 a}\left(13.8 \mathrm{~g}, 88.3 \mathrm{mmol}, 99 \%\right.$, 4:1 mixture of tautomers $\left.\mathbf{5 a} / \mathbf{5} \mathbf{a}^{\prime}\right)$ as a colorless oil.

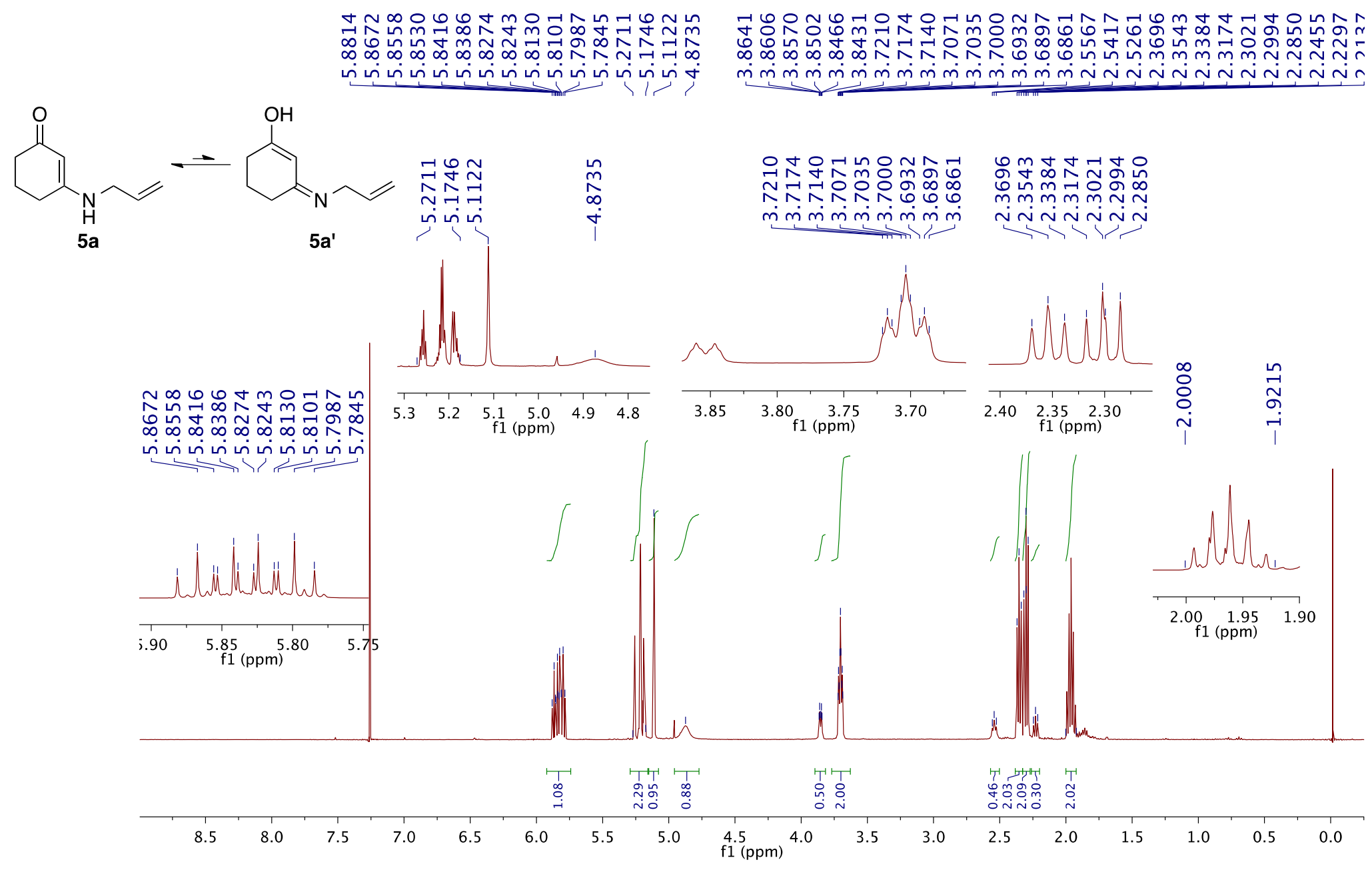




\section{tert-Butyl allyl(3-oxocyclohex-1-en-1-yl)carbamate (6a)}

A solution of enaminone $5 \mathbf{a}(1.00 \mathrm{~g}, 6.61 \mathrm{mmol})$ in $\mathrm{CH}_{2} \mathrm{Cl}_{2}(10 \mathrm{~mL})$ was treated with $\mathrm{Boc} 2 \mathrm{O}(2.10 \mathrm{~g}$, $9.92 \mathrm{mmol})$ and $4-$ (dimethylamino)pyridine $(81 \mathrm{mg}, 0.66 \mathrm{mmol})$ at $0{ }^{\circ} \mathrm{C}$. After stirring for five minutes, the ice bath was removed and stirring was continued for $5 \mathrm{~h}$ at room temperature. The reaction mixture was diluted with water $(20 \mathrm{~mL})$, extracted with $\mathrm{CH}_{2} \mathrm{Cl}_{2}(3 \times 20 \mathrm{~mL})$, and the combined organic layers were washed with brine $(1 \times 20 \mathrm{~mL})$, dried $\left(\mathrm{MgSO}_{4}\right)$ and concentrated in vacuo. After purification with flash column chromatography (EtOAc/heptane 1:7 $\rightarrow 2: 3)$, carbamate 6a (992 mg, $3.95 \mathrm{mmol}, 65 \%)$ was obtained as a colorless oil.

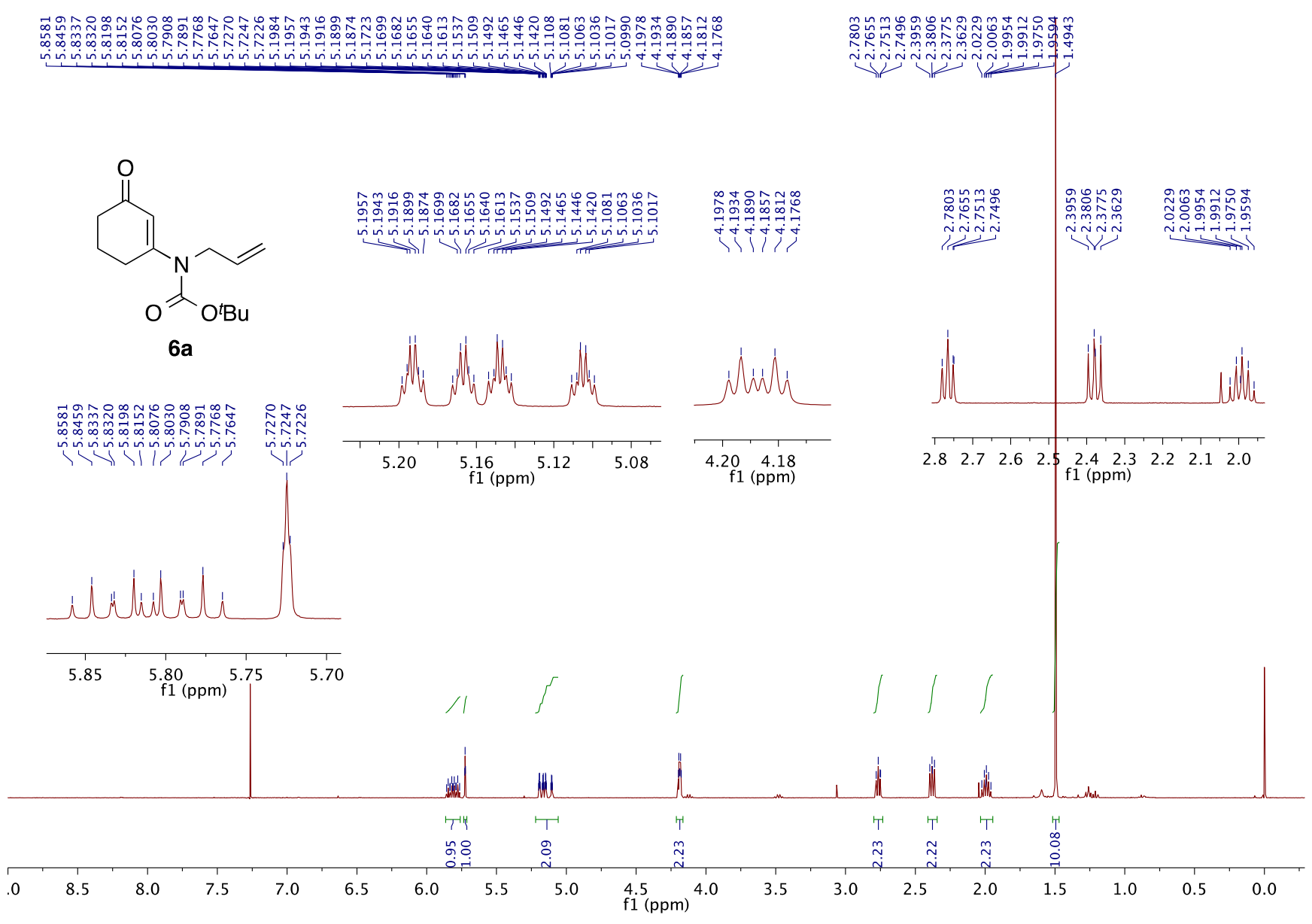




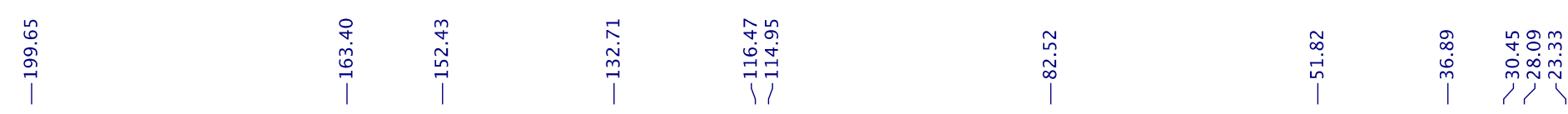

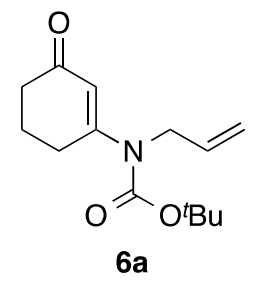

$6 \mathbf{a}$

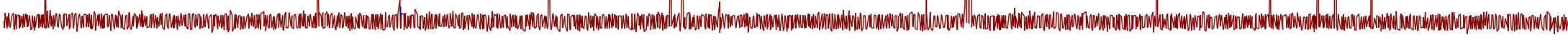

0 


\section{3-(But-3-en-1-ylamino)cyclohex-2-en-1-one (5b)}

A solution of cyclohexane-1,3-dione $(10.0 \mathrm{~g}, 89.2 \mathrm{mmol})$ and but-3-enylamine $(9.51 \mathrm{~g}, 134 \mathrm{mmol})$ in toluene $(180 \mathrm{~mL})$ was refluxed using a Dean-Stark apparatus. The reaction was monitored by TLC, and upon completion $(5 \mathrm{~h})$ the mixture was evaporated under reduced pressure to give enaminone $\mathbf{5 b}(14.6 \mathrm{~g}, 88.3 \mathrm{mmol}, 99 \%)$ as a colorless oil.

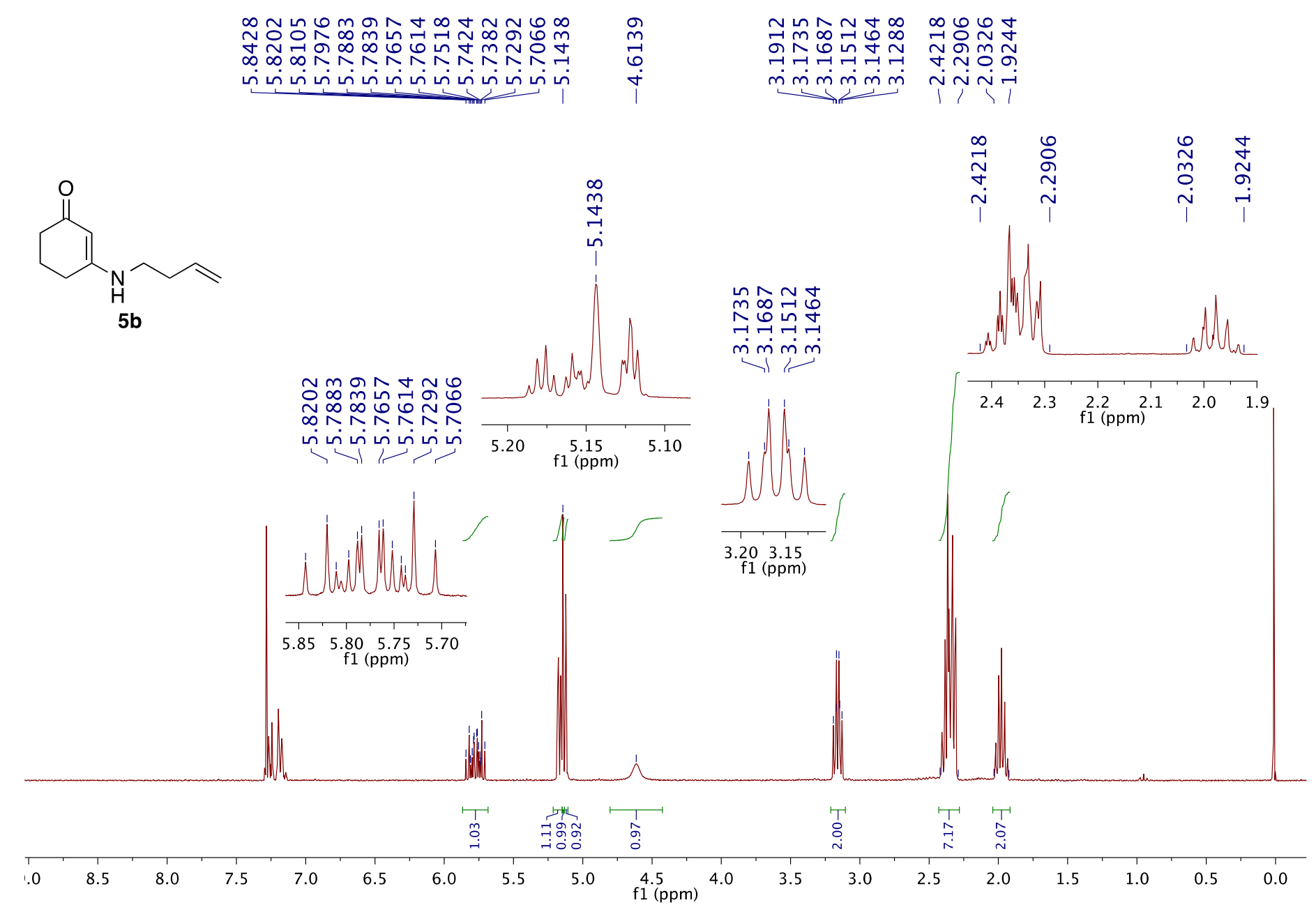




\section{tert-Butyl but-3-en-1-yl(3-oxocyclohex-1-en-1-yl)carbamate (6b)}

A solution of enaminone $5 \mathbf{b}(1.55 \mathrm{~g}, 0.41 \mathrm{mmol})$ in $\mathrm{CH}_{2} \mathrm{Cl}_{2}(30 \mathrm{~mL})$ was treated with $\mathrm{Boc}_{2} \mathrm{O}(3.08 \mathrm{~g}$, $14.1 \mathrm{mmol})$ and $4-$ (dimethylamino)pyridine $(115 \mathrm{mg}, 0.94 \mathrm{mmol})$ at $0{ }^{\circ} \mathrm{C}$. After stirring for 15 minutes, the ice bath was removed and stirring was continued for $6 \mathrm{~h}$ at room temperature. The reaction mixture was diluted with water $(20 \mathrm{~mL})$, extracted with $\mathrm{CH}_{2} \mathrm{Cl}_{2}(3 \times 30 \mathrm{~mL})$, the combined organic layers were washed with brine $(1 \times 30 \mathrm{~mL})$, dried $\left(\mathrm{MgSO}_{4}\right)$ and concentrated in vacuo. After purification with flash column chromatography $(15 \rightarrow 25 \%$ EtOAc/heptane), carbamate $6 \mathbf{b}(1.47 \mathrm{~g}, 5.55 \mathrm{mmol}, 60 \%$ over two steps) was obtained as a colorless oil.

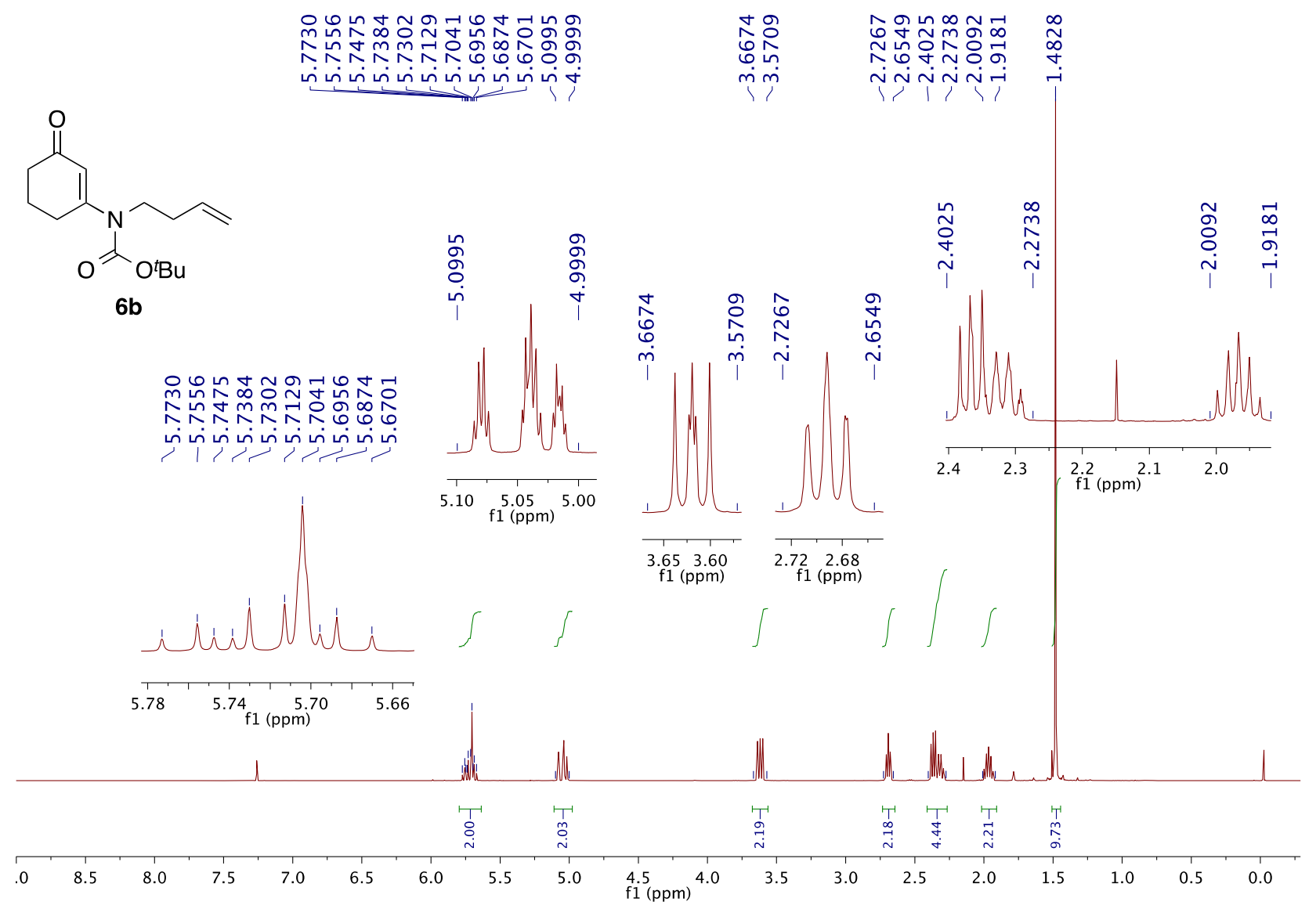




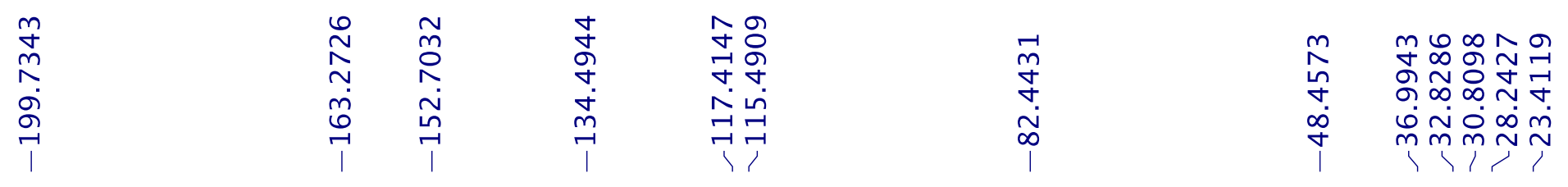
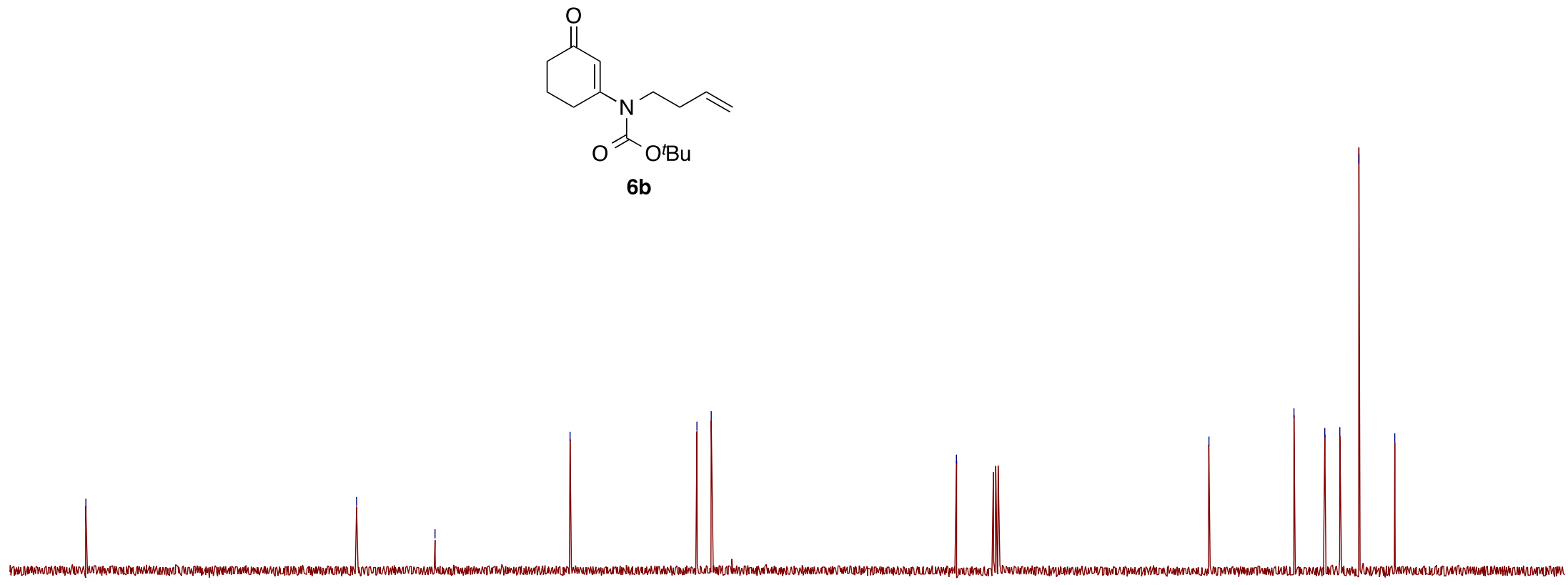

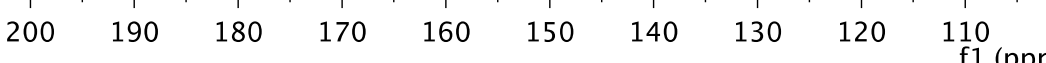


A solution of enaminone $6 \mathbf{a}(4.87 \mathrm{~g}, 19.4 \mathrm{mmol})$ in acetonitrile $(485 \mathrm{~mL}, 40 \mathrm{mM})$ was pumped through FEP tubing (id: $2.7 \mathrm{~mm}$, total volume $140 \mathrm{~mL}$, irradiated volume $128 \mathrm{~mL}$ ) at a flow of $3.5 \mathrm{~mL} / \mathrm{min}$, corresponding to a $36.7 \mathrm{~min}$ irradiation time using $254 \mathrm{~nm} \mathrm{UV}$ light. After concentrating the reaction mixture in vacuo, a 4:1 mixture of compounds 7 and $\mathbf{8}$ (4.69 g, 18.7 mmol, 96\% combined yield) was obtained after a first purification by column chromatography (EtOAc/heptane 1:7 $\rightarrow 1: 4)$. A second purification over silica gel yielded 7 in pure form, along with a mixture of the two cycloadducts.

\section{tert-Butyl (rel-3R,3aS,7aS)-4-oxohexahydro-3,7a-methanoindole-1(2H)-carboxylate (7)}

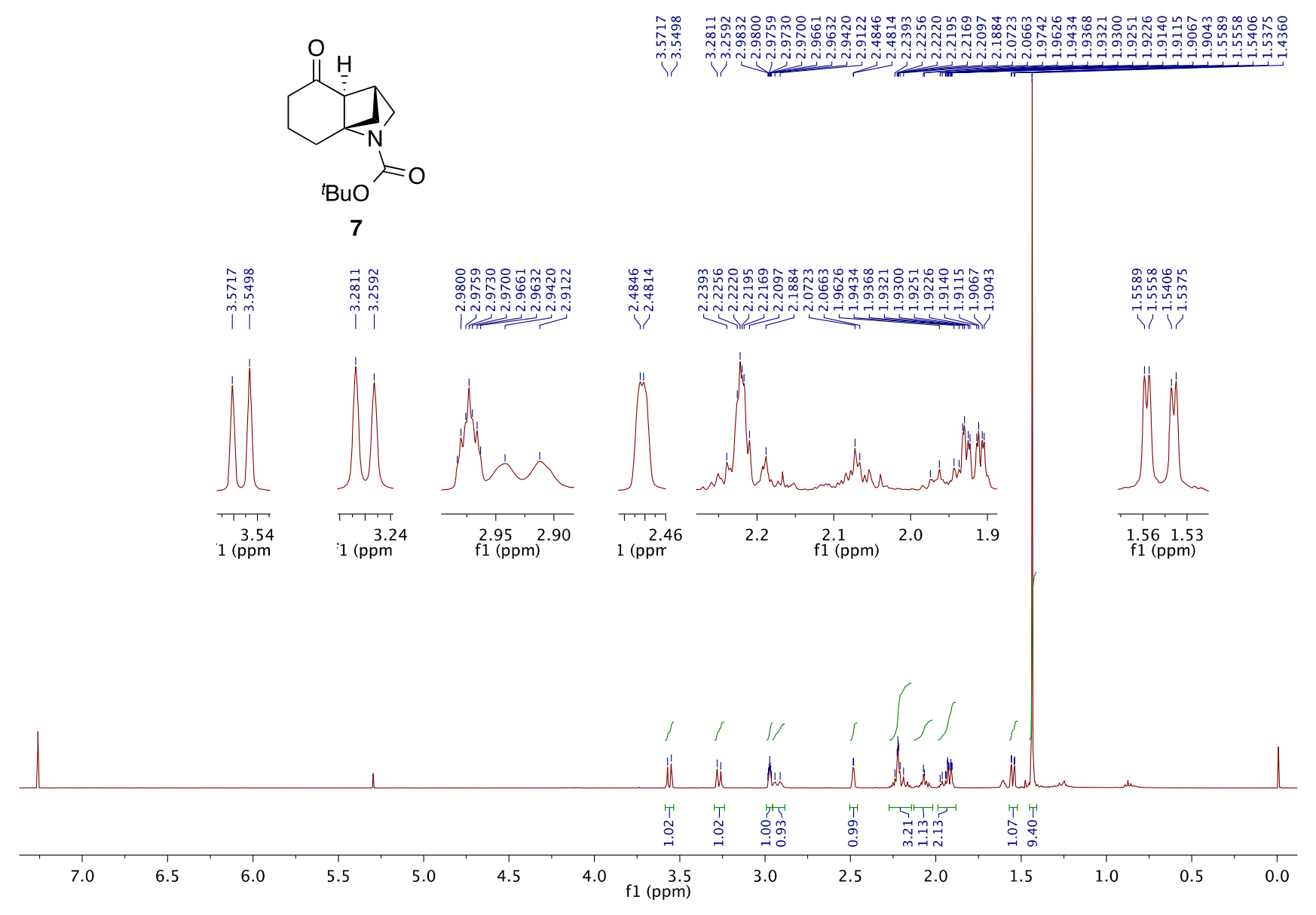



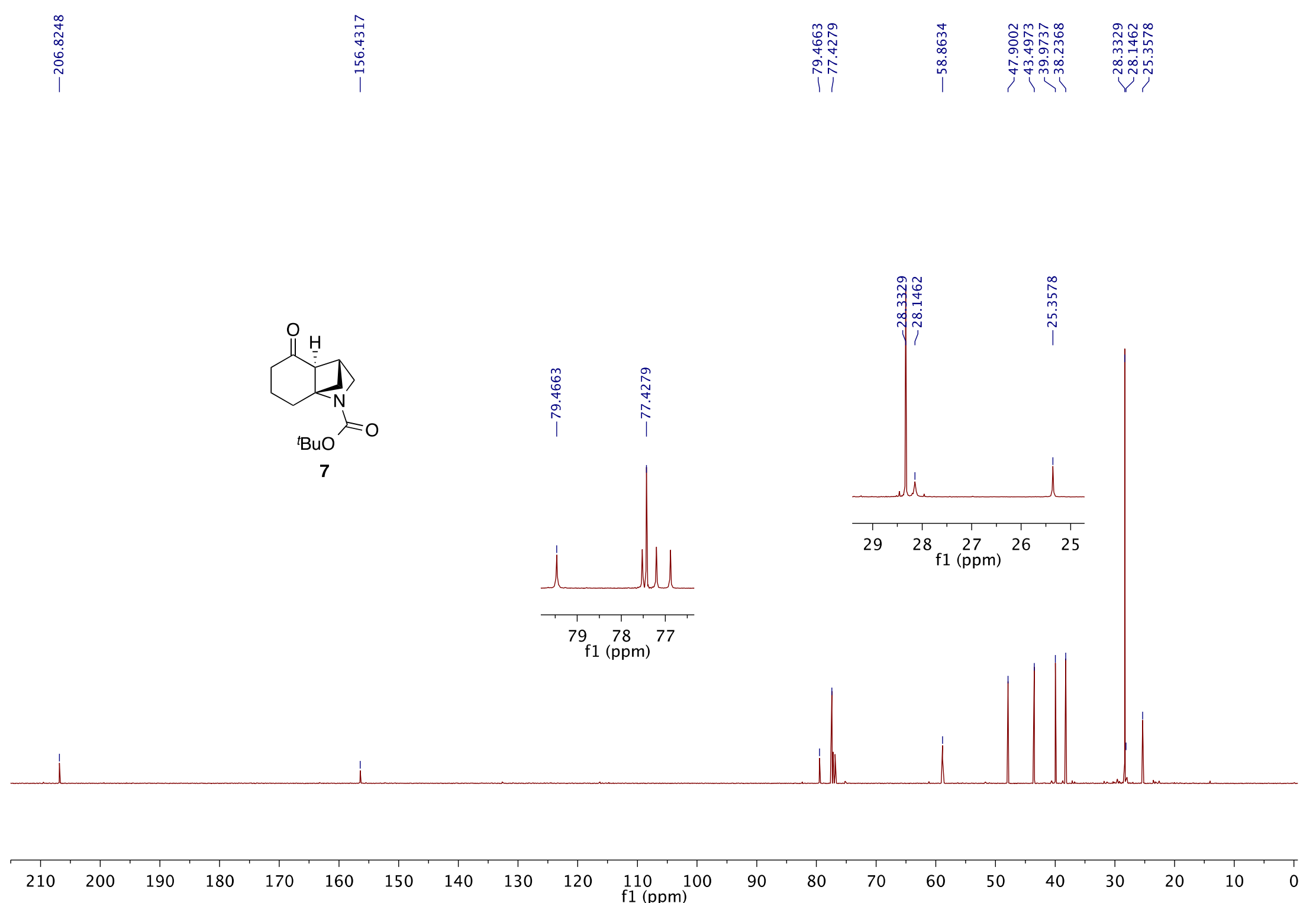
tert-Butyl (rel-1S,4R,6S)-7-0xo-2-azatricyclo[4.4.0.0 $\left.{ }^{1,4}\right]$ decane-2-carboxylate $(8)$

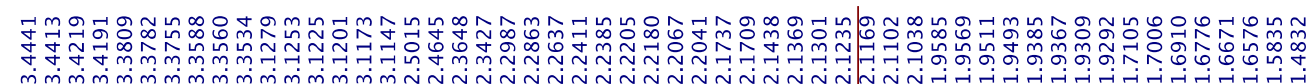

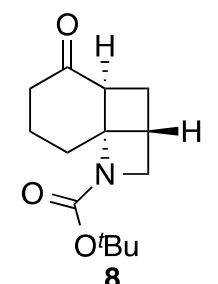

8
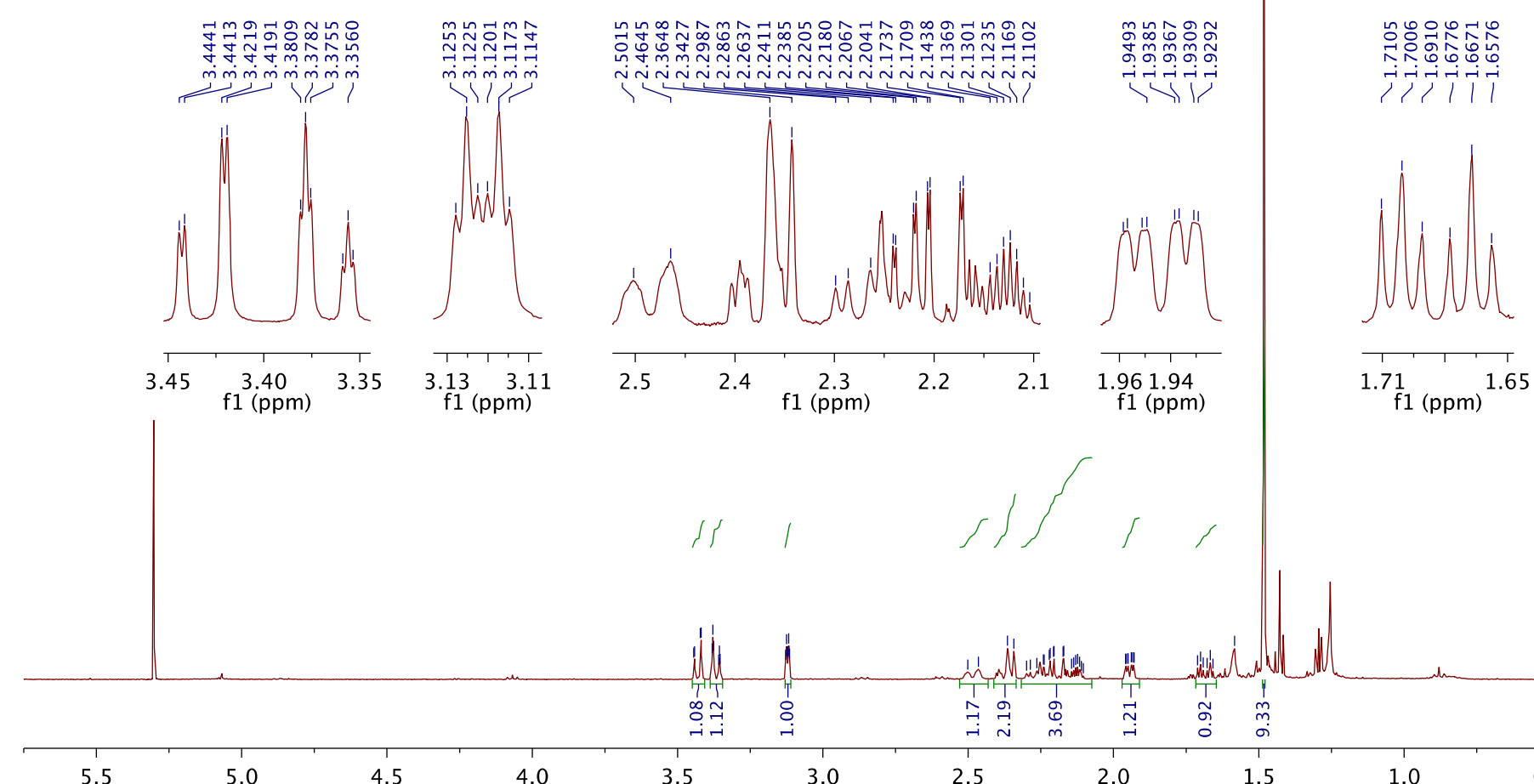

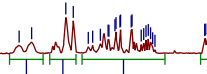

5.5

5.0

4.5

4.0

3.5

$3.0 \mathrm{f} 1(\mathrm{ppm})$
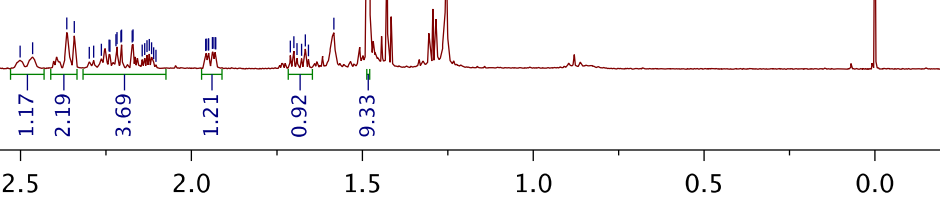


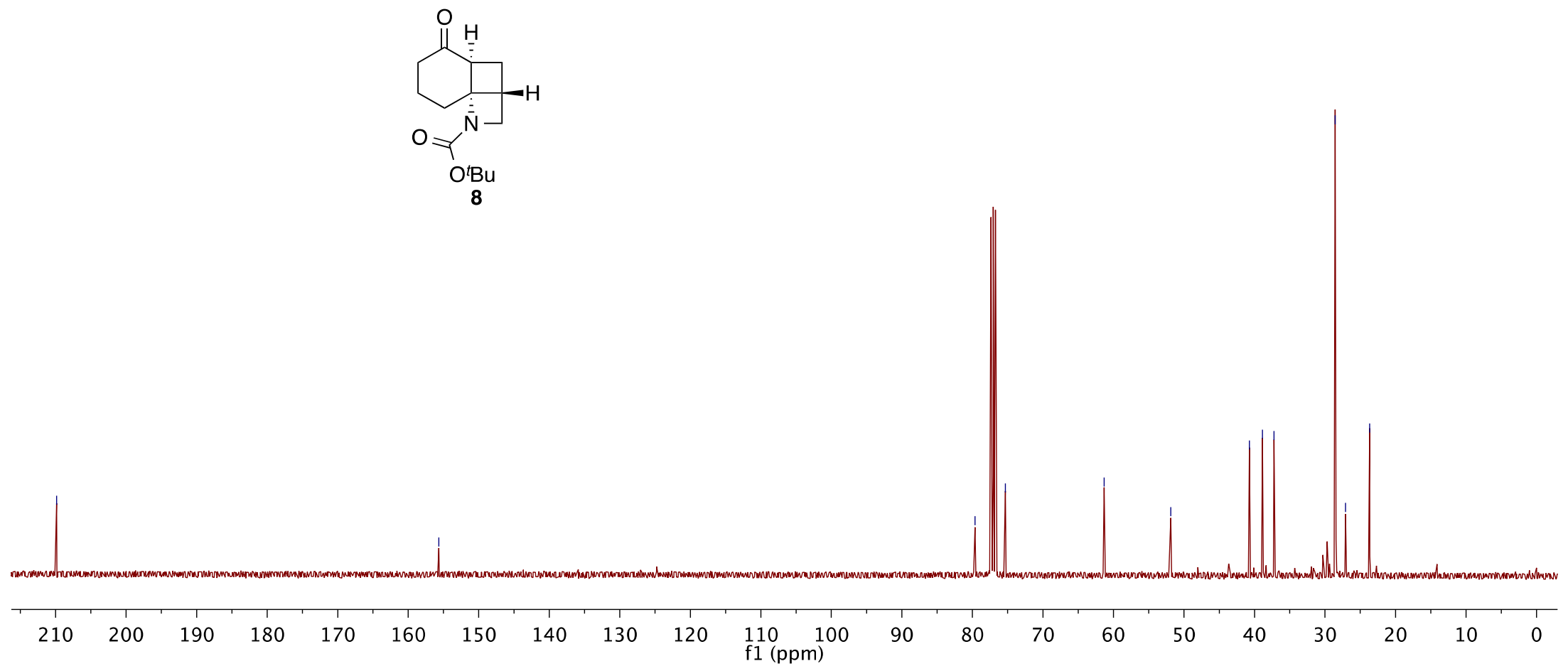




\section{tert-Butyl (rel-3aR,4aS,8aS)-5-oxooctahydrobenzo[1,4]cyclobuta[1,2-b]pyrrole-1(2H)-carboxylate (9)}

A solution of enaminone $\mathbf{6 b}(4.16 \mathrm{~g}, 15.7 \mathrm{mmol})$ in acetonitrile $(530 \mathrm{~mL}, 30 \mathrm{mM})$ was pumped through FEP tubing at a flow rate of $2.88 \mathrm{~mL} / \mathrm{min}$, corresponding to a $40 \mathrm{~min}$ irradiation time using $254 \mathrm{~nm} \mathrm{UV} \mathrm{light.} \mathrm{After} \mathrm{concentrating} \mathrm{the} \mathrm{reaction} \mathrm{mixture} \mathrm{in} \mathrm{vacuo,}$ cycloadduct 9 (3.95 g, $14.9 \mathrm{mmol}, 95 \%$, mixture of rotamers) was obtained as a colorless oil. Upon standing, even at low temperatures, the compound slowly decomposes. Therefore, follow-up reactions were carried out immediately after the photocycloaddition.

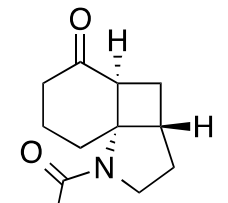

tBuO
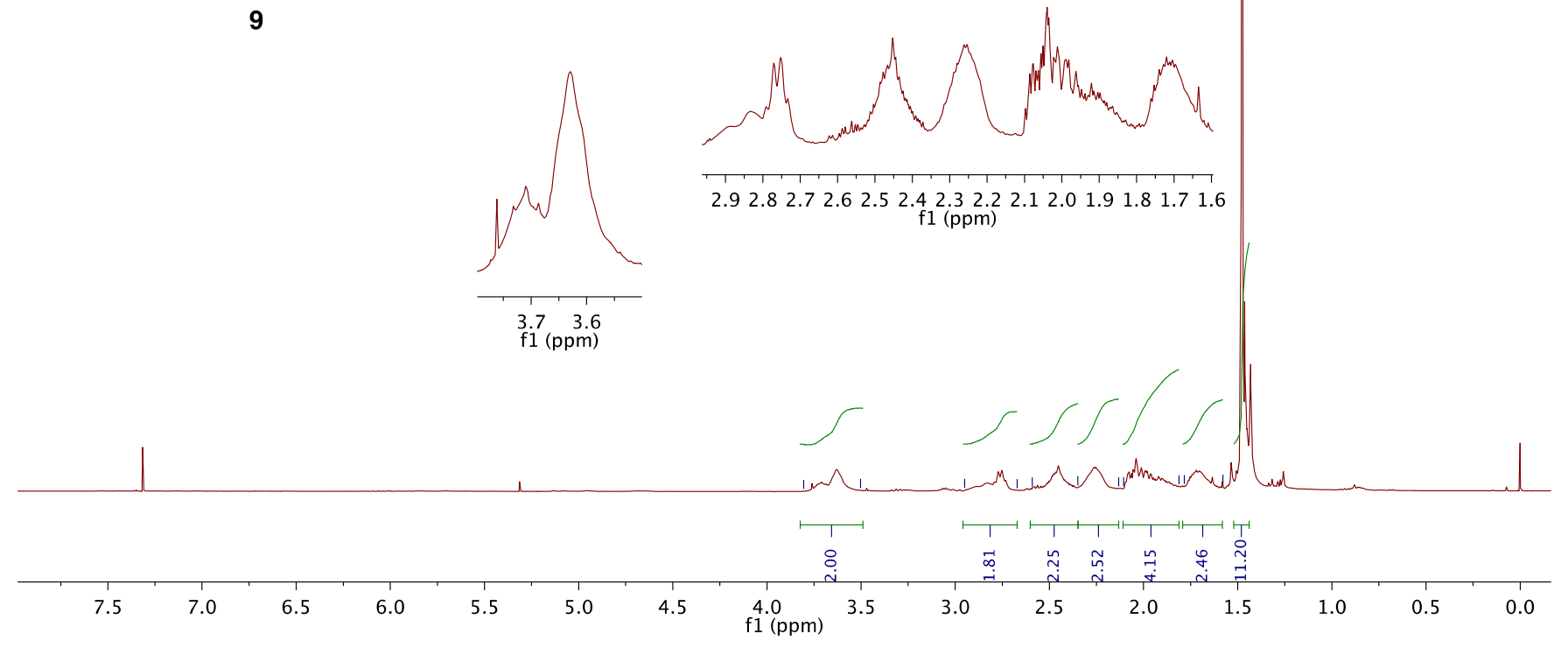

9 


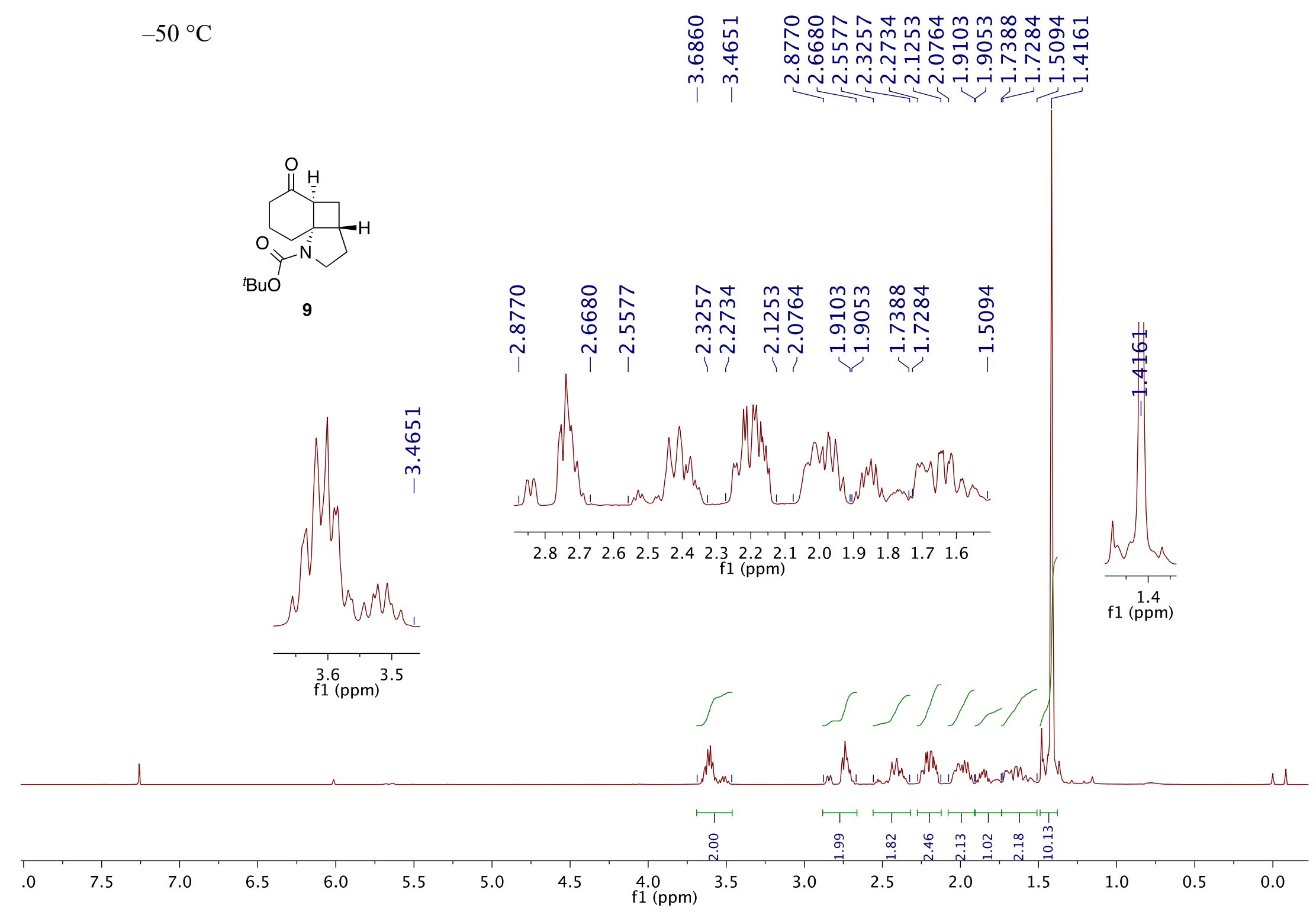




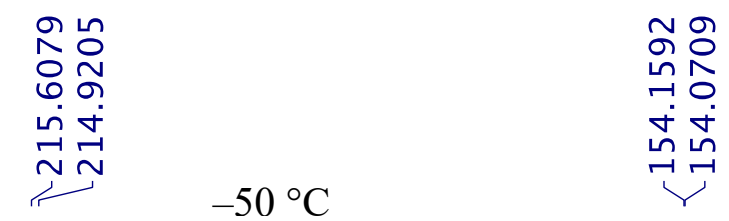

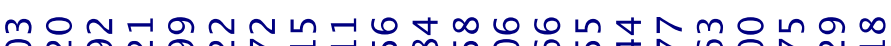
न லீ

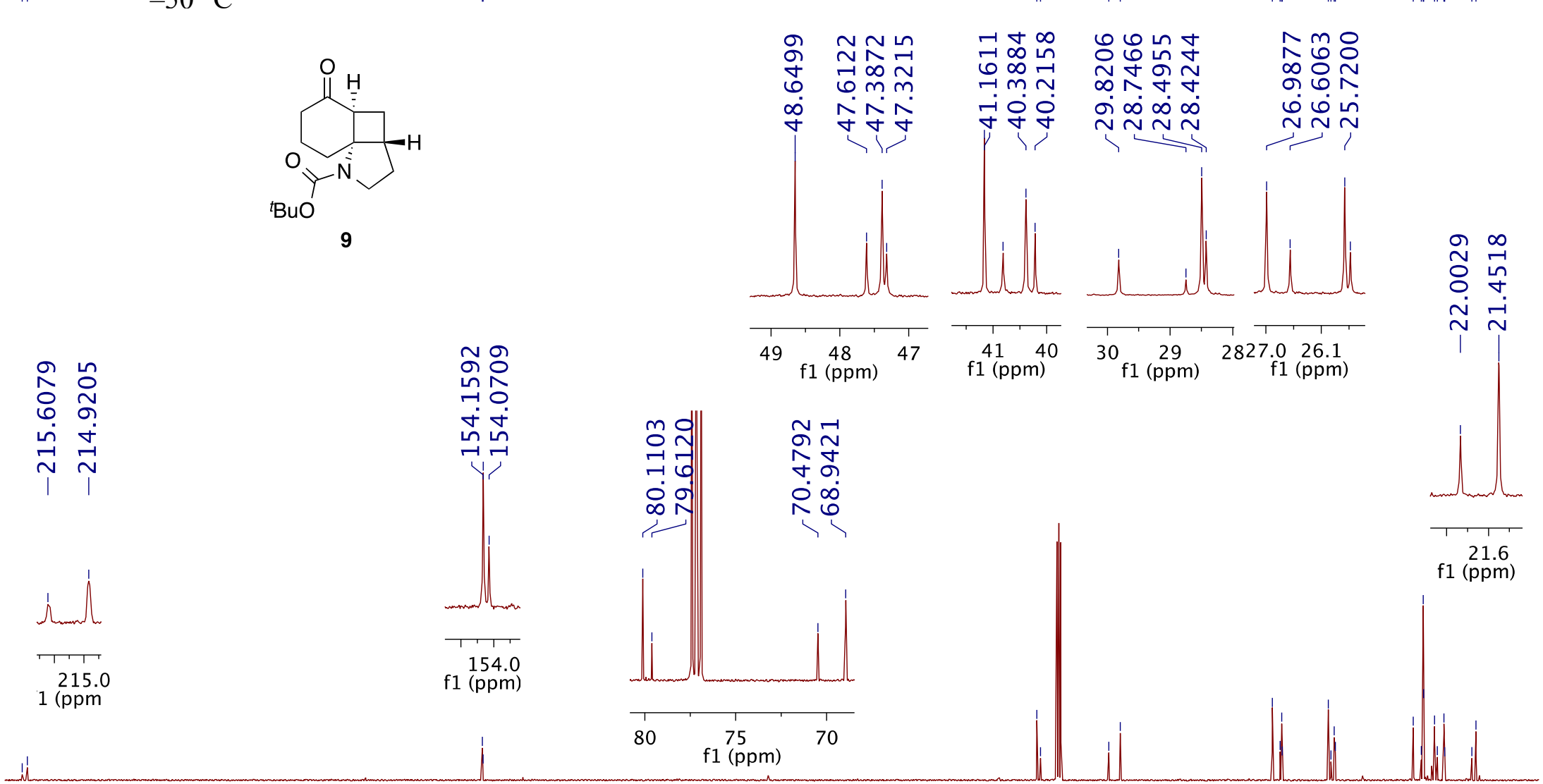

210

$200 \quad 190$

180

160

$150 \quad 140$

$120 \quad 110$

100

90

$70 \quad 60$

(6)

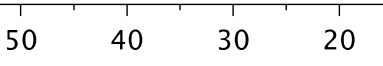




\section{(rel-3R,3aR,4R,7aS)-tert-Butyl 4-(pyrrolidin-1-yl)hexahydro-3,7a-methanoindole-1(2H)-carboxylate (10)}

Acetic acid (24 mg, $0.40 \mathrm{mmol})$, pyrrolidine (28 mg, $0.40 \mathrm{mmol}), \mathrm{NaBH}(\mathrm{OAc}) 3(152 \mathrm{mg}, 0.72 \mathrm{mmol})$ and molecular sieves $(4 \AA)$, were added to a solution of ketone $7(100 \mathrm{mg}, 0.40 \mathrm{mmol})$ in 1,2-dichloroethane $(2 \mathrm{~mL})$. The mixture was stirred at room temperature for 48 $\mathrm{h}$ (more pyrrolidine $[28 \mathrm{mg}, 0.40 \mathrm{mmol}]$ was added after $24 \mathrm{~h})$. The reaction was quenched with water $(2 \mathrm{~mL})$, extracted with $\mathrm{CH}_{2} \mathrm{Cl}_{2}(3 \times$ $5 \mathrm{~mL})$, the combined organic layers were washed with brine $(5 \mathrm{~mL})$, dried $\left(\mathrm{MgSO}_{4}\right)$ and concentrated in vacuo. After purification by column chromatography (EtOAc/heptane 4:1 $\rightarrow 1: 0)$ compound 10 (45 mg, 0.15 mmol, 37\%) was obtained as a colorless oil.
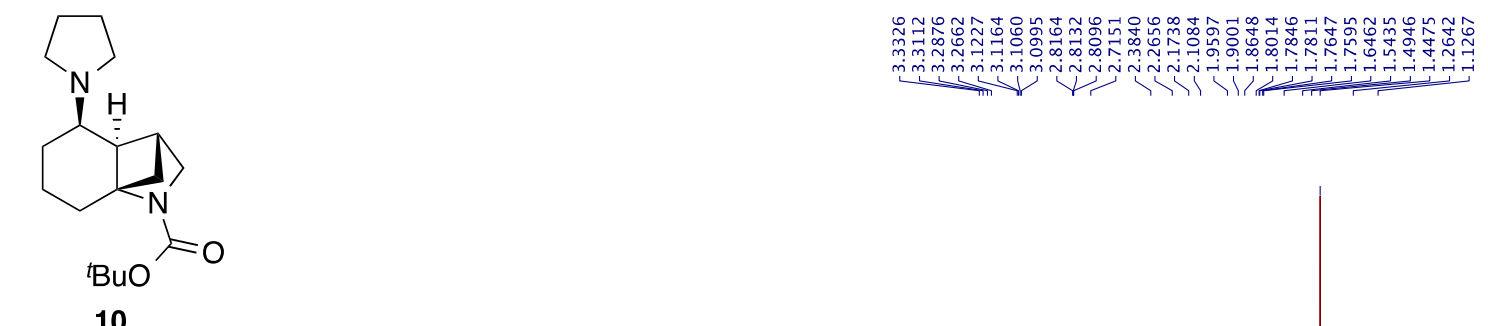

10

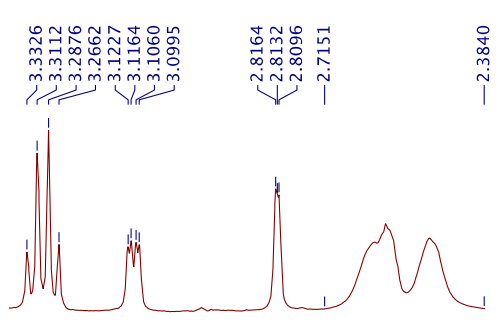

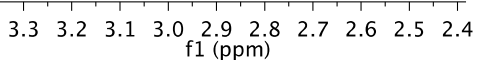
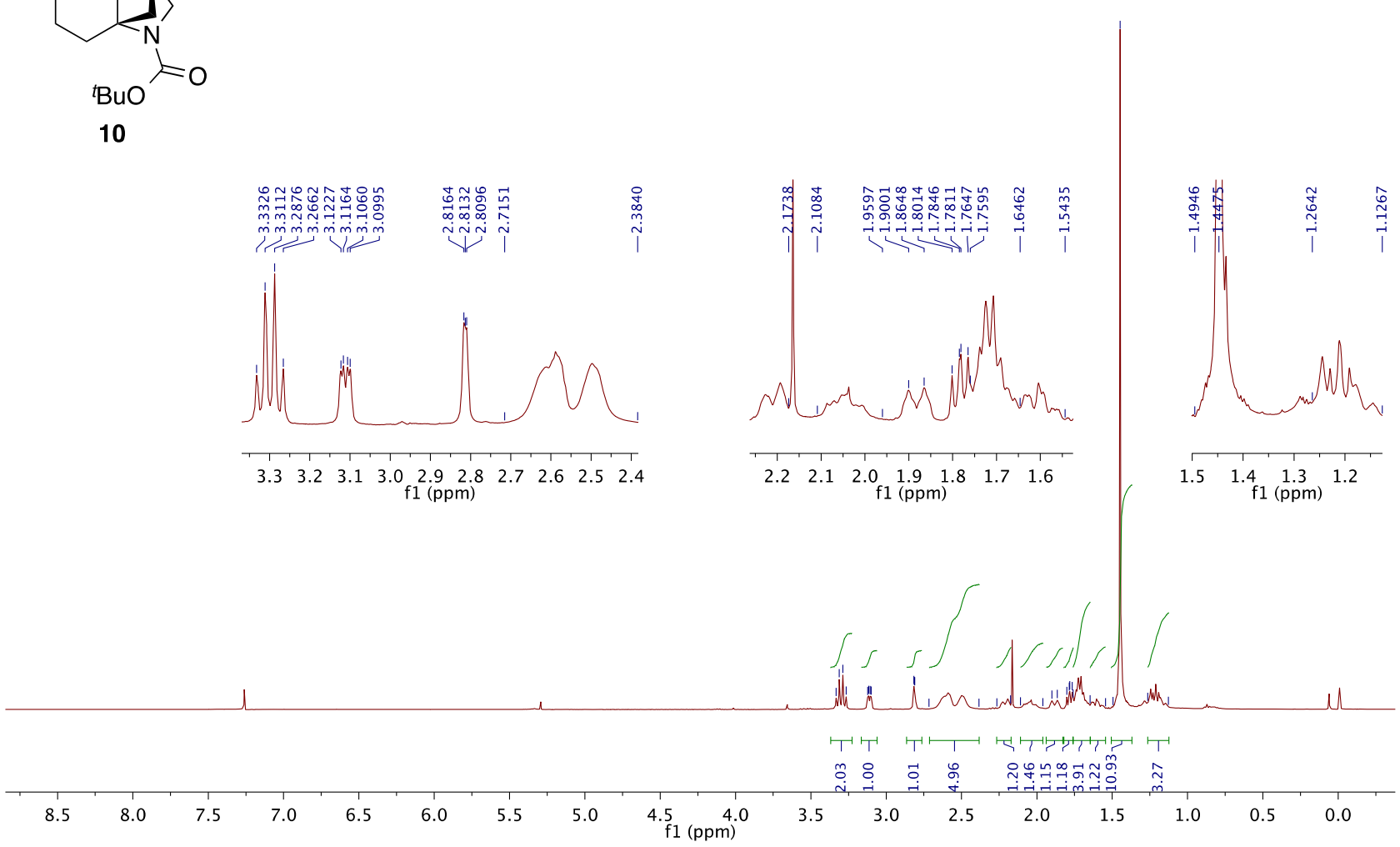

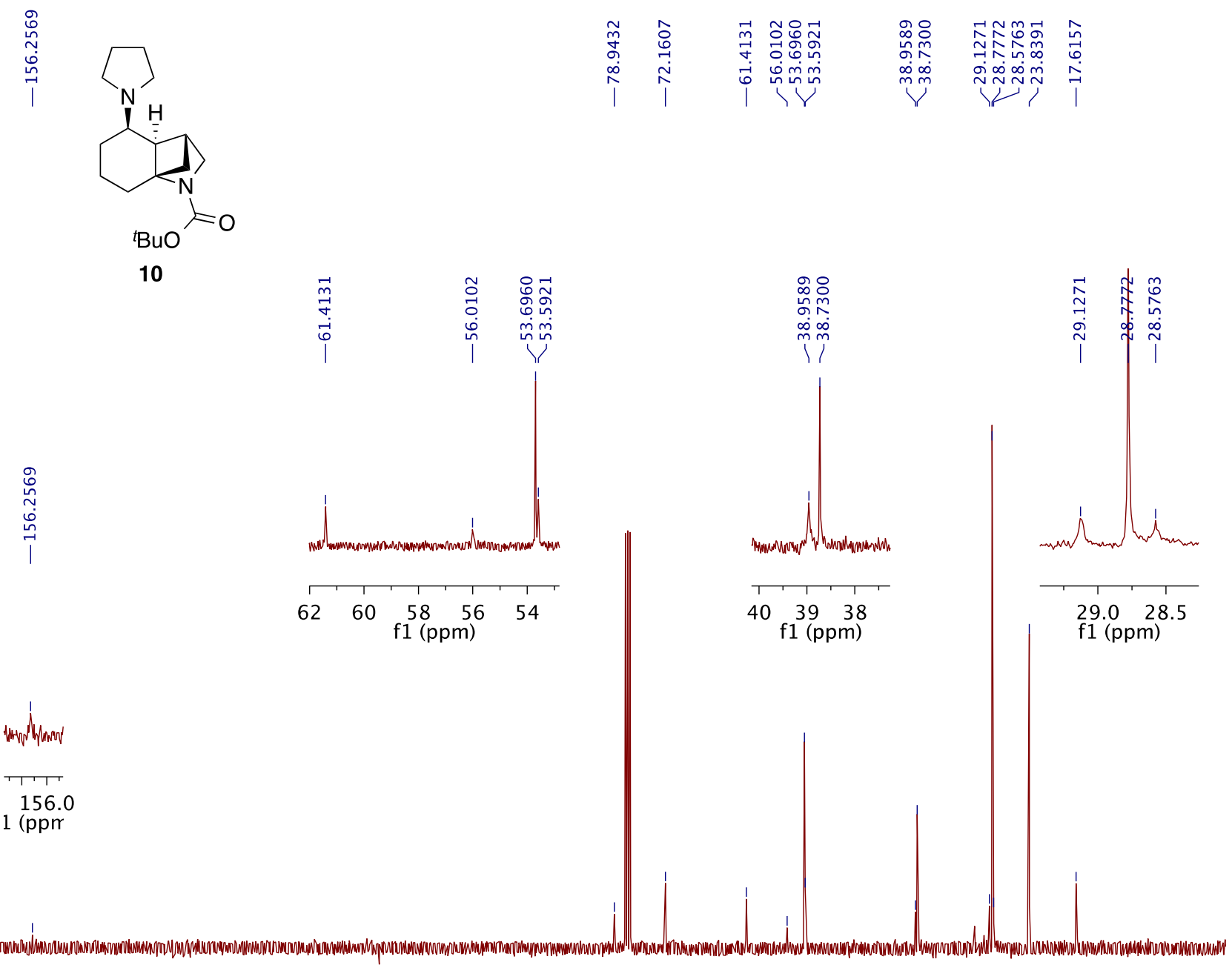

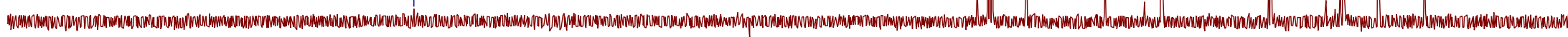

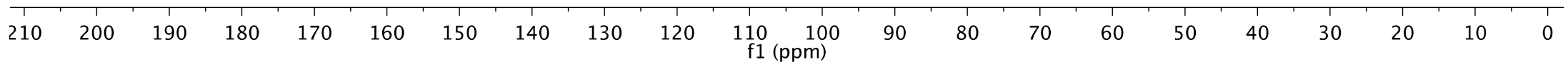


(rel-3R,3aR,4R,7aS)-4-(Pyrrolidin-1-yl)-1-tosyloctahydro-3,7a-methanoindole (11)

A solution of pyrrolidine $10(17 \mathrm{mg}, 0.055 \mathrm{mmol})$ was stirred at room temperature in a $\mathrm{TFA} / \mathrm{CH}_{2} \mathrm{Cl}_{2} \mathrm{mixture}(1: 1)$ for $20 \mathrm{~min}$. The mixture was concentrated, dissolved in $\mathrm{CH}_{2} \mathrm{Cl}_{2}(1 \mathrm{~mL})$ and at $0{ }^{\circ} \mathrm{C}$ treated with triethylamine $(17 \mathrm{mg}, 0.17 \mathrm{mmol})$ and $p$-toluenesulfonyl chloride $(11 \mathrm{mg}, 0.055 \mathrm{mmol})$. After stirring for $2.5 \mathrm{~h}$ at room temperature, the reaction was quenched with water $(1.5 \mathrm{~mL})$, extracted with $\mathrm{CH}_{2} \mathrm{Cl}_{2}(3 \times 3 \mathrm{~mL})$, the combined organic layers were washed with brine $(4 \mathrm{~mL})$, dried $\left(\mathrm{MgSO}_{4}\right)$ and concentrated in vacuo. After purification by column chromatography (EtOAc/heptane $5 \rightarrow 25 \%$ ) sulfonamide 11 (14 mg, 0.039 mmol, 71\% over two steps) was obtained as a colorless oil.

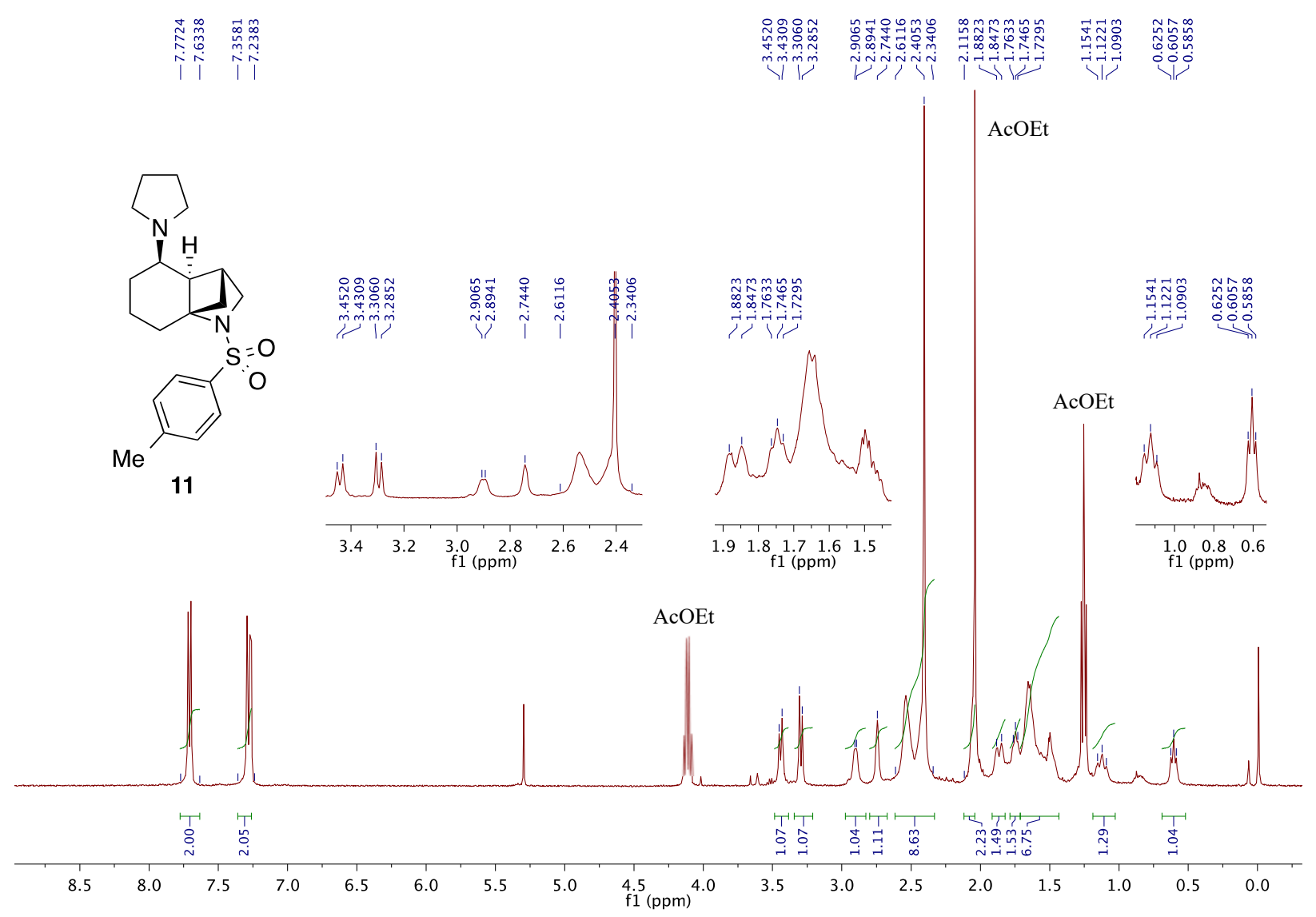


<smiles></smiles><smiles>CCCC1=CN1S(=O)(=O)c1ccc(C)cc1</smiles>

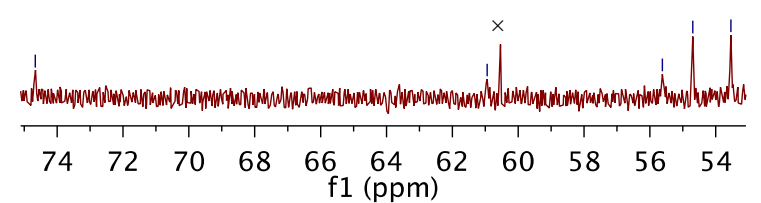

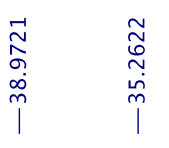

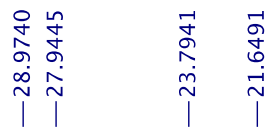

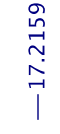

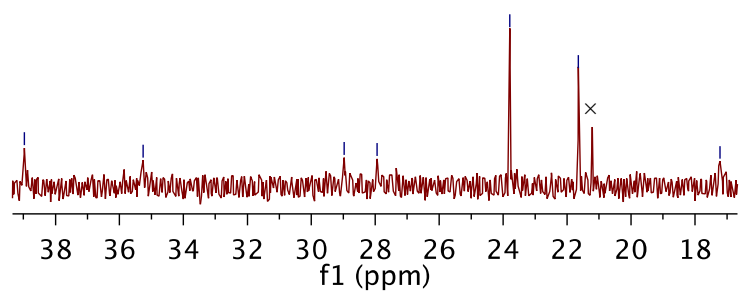

AcOEt $x$

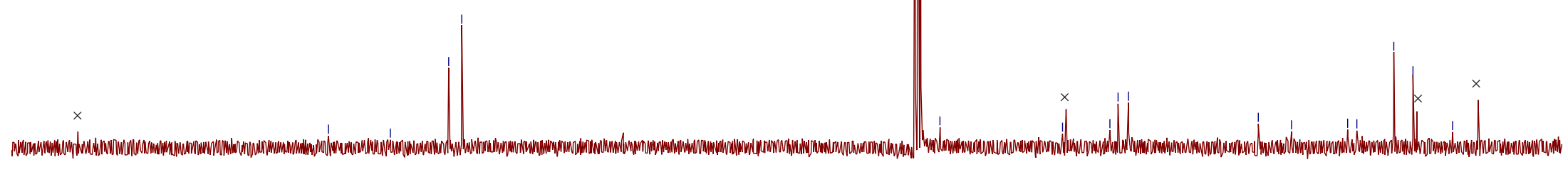

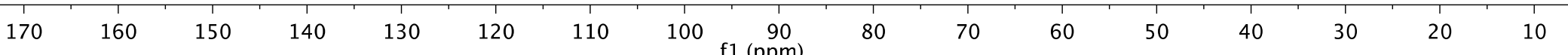




\section{tert-Butyl (rel-3aR,4aR,8aS)-5-Phenyl-3,3a,4,4a,7,8-hexahydrobenzo[1,4]cyclobuta[1,2-b]pyrrole-1(2H)-carboxylate (13)}

NaHMDS (643 $\mu \mathrm{L}$ of a $2 \mathrm{M}$ solution in THF, $1.286 \mathrm{mmol})$ was added to a solution of compound 9 (310 $\mathrm{mg}, 1.168 \mathrm{mmol}) \mathrm{in} \mathrm{Et} 2 \mathrm{O}$ (3 $\mathrm{mL})$ at $-20^{\circ} \mathrm{C}$, and after $20 \mathrm{~min} \mathrm{PhNTf}_{2}(417 \mathrm{mg}, 1.168 \mathrm{mmol})$. After warming to room temperature, the mixture was stirred for 4 hours. Then, the temperature was lowered to $-20^{\circ} \mathrm{C}$ and NaHMDS $(117 \mu \mathrm{L}$ of a $2 \mathrm{M}$ solution in THF, 0.117 mmol) was added and after 20 min $\mathrm{PhNTf}_{2}(42 \mathrm{mg}, 0.117 \mathrm{mmol}$ ). After $4 \mathrm{~h}$, the same additions were performed. The reaction mixture was stirred for $10 \mathrm{~h}$ at room temperature, and then washed with saturated aqueous $\mathrm{NaHCO}_{3}(2 \times 5 \mathrm{~mL})$ and water $(5 \mathrm{~mL})$. The combined aqueous phase was reextracted with $\mathrm{Et}_{2} \mathrm{O}(2 \times 12 \mathrm{~mL})$. The combined organic layers were dried $\left(\mathrm{MgSO}_{4}\right)$, and concentrated in vacuo to obtain vinyl triflate 12 (slightly contaminated with PhNHTf). The crude mixture was used for the Suzuki coupling reaction. A mixture of vinyl triflate 12, $\mathrm{Pd}(\mathrm{OAc})_{2}(38 \mathrm{mg}, 0.17 \mathrm{mmol}), \mathrm{PPh}_{3}(133 \mathrm{mg}, 0.507 \mathrm{mmol})$ and $1.0 \mathrm{M}$ aqueous sodium carbonate $(2.34 \mathrm{~mL})$ were dissolved in $1,4-$ dioxane $(6.5 \mathrm{~mL})$. The mixture was stirred for 30 minutes at room temperature. Then, phenylboronic acid $(171 \mathrm{mg}, 1.402 \mathrm{mmol}) \mathrm{was}$ added and the mixture was stirred for 20 hours. The reaction was quenched with water $(4 \mathrm{~mL})$ and extracted with EtOAc $(3 \times 5 \mathrm{~mL})$. The combined organic fractions were washed with brine $(8 \mathrm{~mL})$, dried $\left(\mathrm{MgSO}_{4}\right)$, concentrated in vacuo and purified via silica column chromatography (EtOAc/heptane $0 \rightarrow 7 \%$ ) to yield compound 13 (156 mg, $0.480 \mathrm{mmol}, 41 \%$ over two steps) as a white solid. 


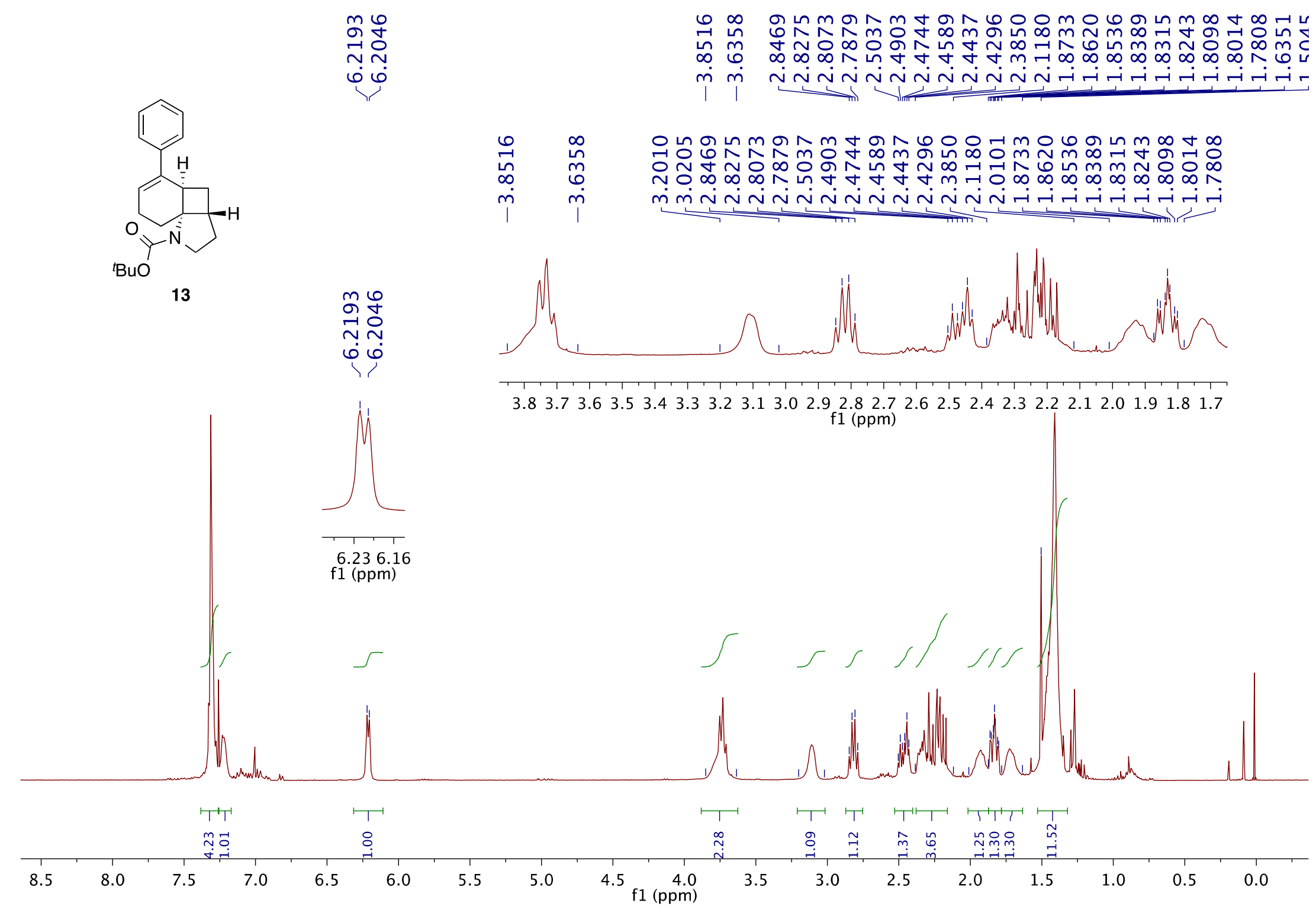



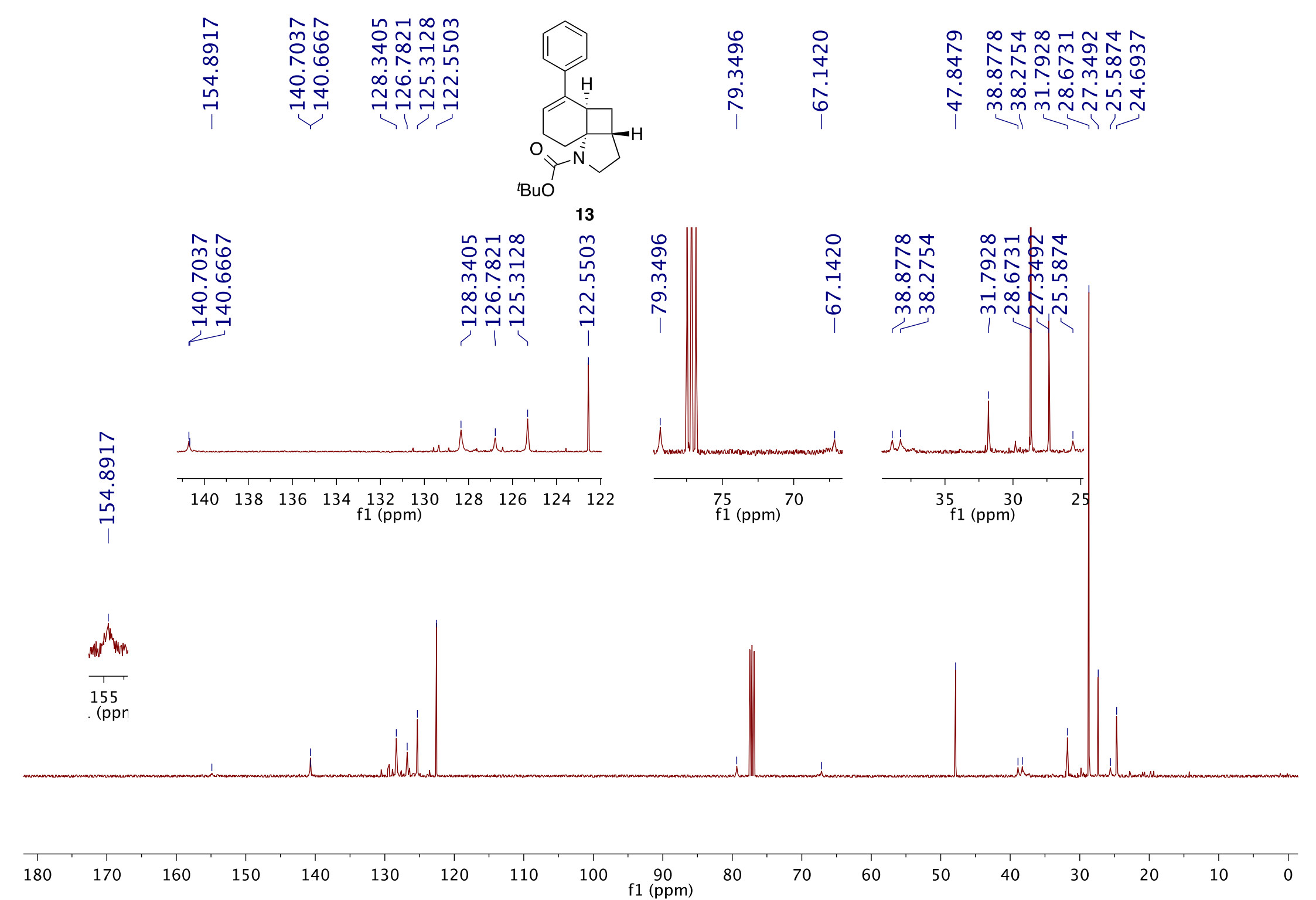


\section{(rel-3aR,4aR,8aS)-5-Phenyl-1-tosyl-1,2,3,3a,4,4a,7,8-octahydrobenzo[1,4]cyclobuta[1,2-b]pyrrole (14)}

A solution of Suzuki product $13(27 \mathrm{mg}, 0.083 \mathrm{mmol})$ was stirred at room temperature in a TFA/ $\mathrm{CH}_{2} \mathrm{Cl}_{2} \mathrm{mixture}(1: 1,2 \mathrm{~mL})$ for $15 \mathrm{~min}$. The mixture was concentrated, dissolved in $\mathrm{CH}_{2} \mathrm{Cl}_{2}(1 \mathrm{~mL})$ and at $0{ }^{\circ} \mathrm{C}$ treated with triethylamine $(21 \mathrm{mg}, 0.207 \mathrm{mmol})$ and $\mathrm{p}$ toluenesulfonyl chloride $(16 \mathrm{mg}, 0.084 \mathrm{mmol}$ ). After stirring for $2.5 \mathrm{~h}$ at room temperature, the reaction was quenched with a saturated solution of $\mathrm{NaHCO}_{3}(1 \mathrm{~mL})$, extracted with $\mathrm{CH}_{2} \mathrm{Cl}_{2}(3 \times 2 \mathrm{~mL})$, the combined organic layers were washed with brine $(2 \mathrm{~mL})$, dried $\left(\mathrm{MgSO}_{4}\right)$ and concentrated in vacuo. After purification by column chromatography (EtOAc/heptane (1:5) sulfonamide 14 (29 mg, 0.079 mmol, $95 \%$ over two steps) was obtained as a white solid.

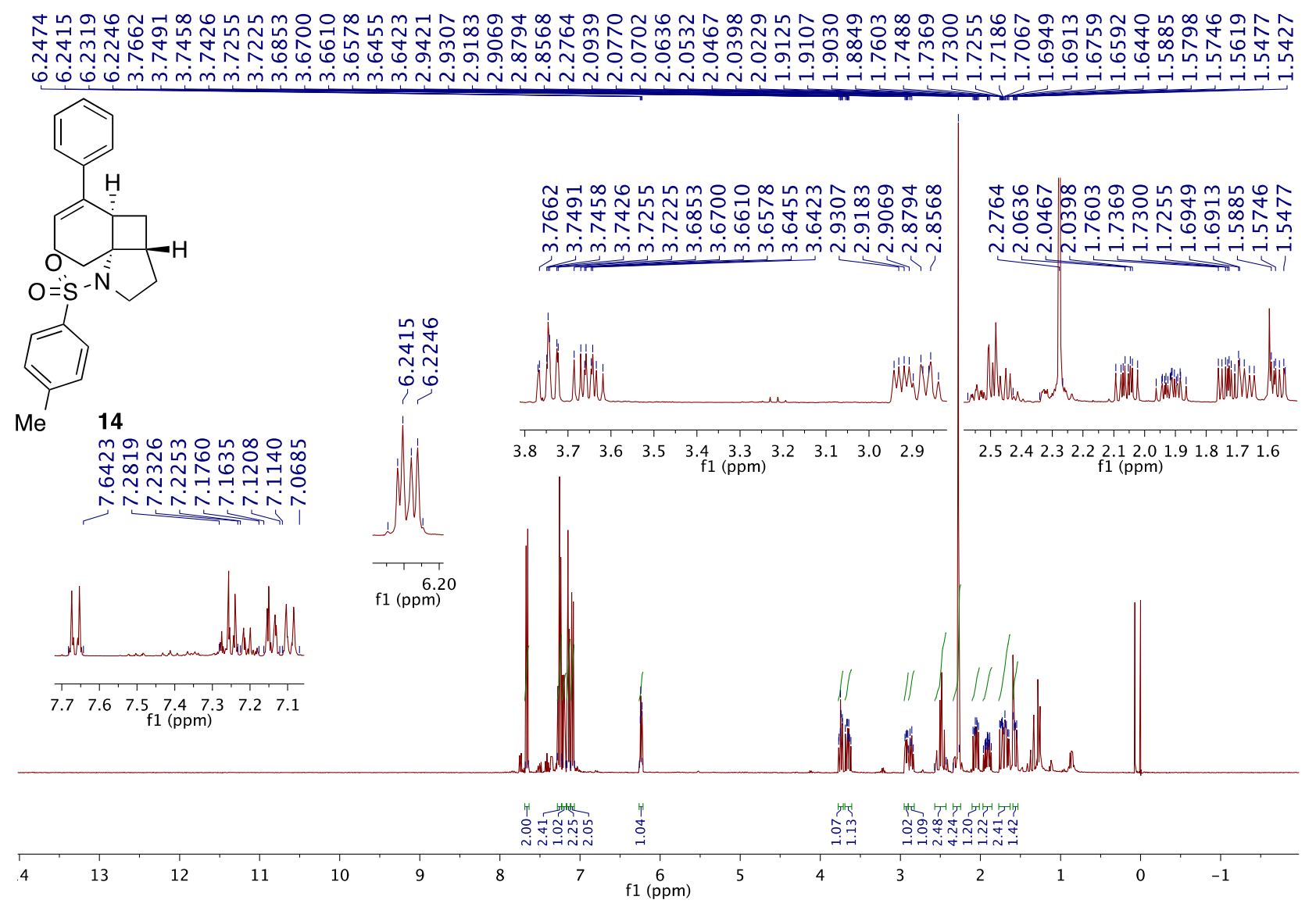




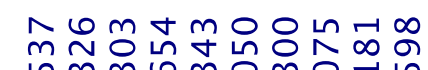
ผึ

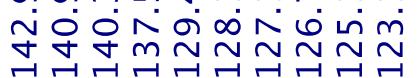

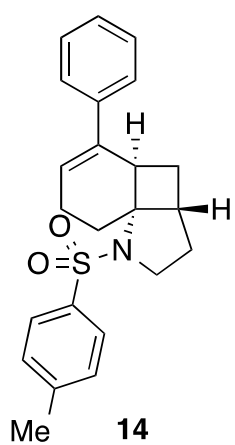

\begin{tabular}{l}
$m$ \\
\multirow{2}{*}{} \\
$\infty$ \\
$i$
\end{tabular}
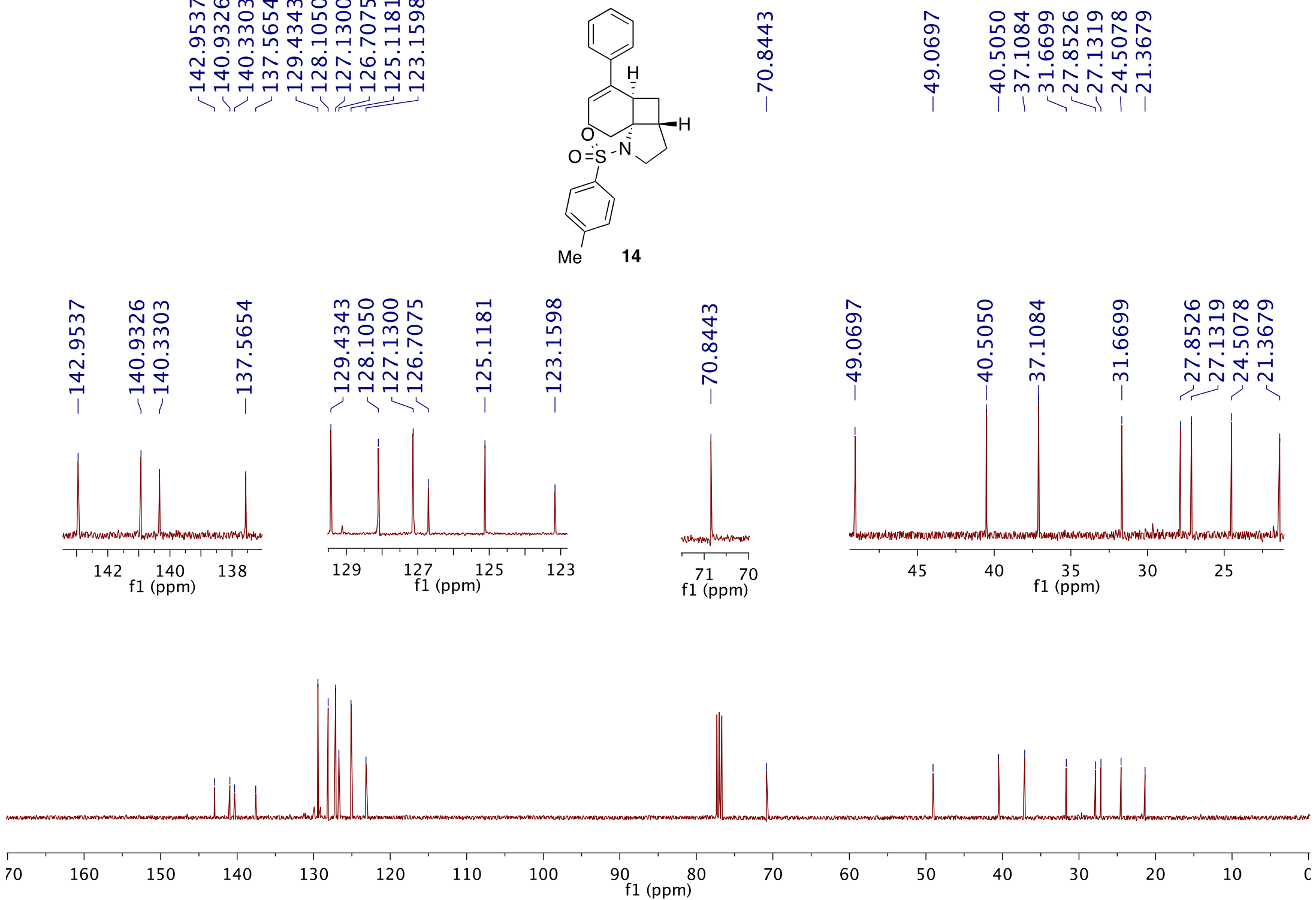